\title{
ALIRAN PAHAM AGAMA ALLAH ALA PARURU DAENG TAU
}

\section{Faith of Understanding Religion of Allah Ala Paruru Daeng Tau}

\author{
Saprillah* \\ *Balai Litbang Agama Makassar \\ Jl. A. P. Pettarani No. 72 Makassar \\ Email: pepi litbang@vahoo.com.
}

Koreksi naskah 1 tanggal 5 Juni 2012. Koreksi naskah II tanggal 13 Juni 2012. Finalisasi Naskah 9 Oktober 2012

\begin{abstract}
Abstrak
Penelitian ini adalah studi kasus yang dilakukan sebagai respon atas pemberitaan media massa lokal di Sulawesi Selatan tentang seorang lelaki yang bernama Paruru Daeng Tau sedang menyebarkan aliran sesat. Tujuan dari penelitian adalah untuk menggambarkan apa yang sesungguhnya dipahami Paruru sebagai ajaran Agama Allah. Penelitian ini tidak bermaksud untuk menjadi bagian dari proses "penyesatan" Paruru tetapi untuk menyediakan informasi sedalam mungkin tentang Paruru dan Agama Allah-nya.

Secara umum penelitian ini menemukan bahwa Paruru memang telah keluar dari agama lamanya, Islam dan sedang membangun cara pandang agama sendiri yang disebut Agama Allah, agama yang diyakininya sebagai Agama Nabi Adam. Penguasa Alam dalam cara pandang Paruru memiliki struktur (13 struktur) yang dipimpin oleh Allahu Akbar, dan memiliki tatacara peribadatan sendiri dengan bahasa Makassar sebagai bahasa pengantarnya.

Kasus Paruru "mungkin" menarik didiskusikan dalam kerangkaperspektif sufistik. Pendekatan sufistik memberi ruangyang dinamis, tidak hitam-putih, dan tidak tendensius dalam melihat kasus spritualisme yang "nyeleneh" seperti ini. Paruru sedang mengalami kebingungan spritualitas, mendapatkan pengetahuan yang berserakan sehingga perlu mendapatkan penataan spiritual (terutama penataan syariat) dari para pemuka agama.
\end{abstract}

Kata Kunci: Paham Keagamaan, Agama Allah, Parurur Daeng Tau

\begin{abstract}
This study is a case study carried out in response to the local news media in South Sulawesi about a man named Daeng Paruru Tau is spreading a cult. The purpose of this study is to describe what is actually understood by Paruru as the teaching of Religion of Allah. This study does not intend to become part of the process of "misdirection" ofParuru but as deep as possible to provide information about Paruru and his religion of Allah. In general, the study found that Paruru indeed been out of the old religion, Islam, and is building its own religious worldview called Religion of Allah, which he attributed as religion prophet Adam. Natural rulers in the perspective of Paruru have structures (13 structures) led by Allahu Akbar, and has its own procedures worship with Makassareese language as a language of instruction.

The case ofParuru' 'maybe " interesting discussion within the framework ofSufi perspective. The approach of Sufi provide a dynamic space, not black and white, and did not see the case of spritualisme tendentious in the "eccentric" like this. Paruru are experiencing confusion spirituality, get knowledge scattered should receive spiritual arrangement (especially structuring Shariah) from religious leaders.
\end{abstract}

Keywords: Understanding of Religoin, Religion of Allah, Paruru Daeng Tau

\section{PENDAHULUAN}

$\mathrm{T}$ liba-tiba saja Paruru Daeng Patau menjadi perbincangan masyarakat Makassar ketika Koran Harian Fajar dan Tribun Timur memberitakannya secara ekslusif selama tiga hari berturut pada awal Januari. Paruru kemudian menjadi perhatian ketika pihak Kandepag Kota Makassar memanggil Paruru untuk mempertanggungjawabkan pemahaman yang dinilai menyimpang. Paruru menjadi aneh karena dianggap telah mengajarkan ajaran yang menyimpang dari ajaran Islam. Paruru dianggap telah merevisi syahadat dengan menghilangkan lafadz asyhaduanna muhammadan rasulullah, dan karena itu Paruru disesatkan dan dilarang menyebarkan ajarannya.

Fenomena Paruru bukanlah fenomena baru dalam masyarakat Islam. Kelompok-kelompok Islam yang 
menyempal dari ajaran pokok Islam telah bermunculan bahkan beberapa saat setelah kematian Nabi Muhammad. Musailama Al-Kadzdzab muncul ke permukaan dengan mengklaim diri sebagai nabi baru yang dapat memproduksi wahyu yang sama dengan Alquran, ia menolak membayar zakat, dan akhirnya ia terbunuh oleh serangan pasukan Khalifah Abu Bakar.

Kelompok Islam sempalan yang cukup melegenda dalam sejarah Islam adalah kelompok Zindiq dari Persia. Kelompok ini tidak hanya muncul sebagai "bentuk lain" dari Islam tetapi juga melakukan kritik terhadap isu-isu fundamental dalam Islam terutama konsep kenabian. Misalnya Ibnu Ar-Rawandi yang menganggap syariat yang diajarkan Nabi Muhammad seperti shalat, thawaf adalah hal yang tidak masuk akal atau Muhammab bin Zakariah bin Ar-Razy yang menolak seluruh kenabian.

Sejarah Islam dalam konteks Indonesia jug a tidak terlepas dari munculnya nalar-nalar "sempalan". Yang paling populer adalah Syekh Siti Jenar. Seorang syekh yang diyakini berasal dari cacing kemudian berubah menjadi manusia dan mengajarkan teologi penyatuan antara manusia dan Tuhan, manunggaling kawuloGusti. Gerakan Siti Jenar hadir melakukan kritik terhadap integrasi politik dan agama melalui lembaga para wali.

Pasca reformasi, gerakan sempalan di Indonesia muncul secara massif, mulai dari revitalisasi Ahmadiyah, Lia Eden, Al-qiyadah Al-Islamiyah, Qur'an Suci, Satrio Piningit, shalat dwi-bahasa Yusman Roy, shalat bersiul Sumardi, Aliran Kebatinan ala Madi, An-Nadzir, hingga yang paling baru (dalam konteks Sulawesi Selatan) munculnya Paruru yang menyebarkan Agama Allah.

Munculnya kelompok yang dianggap sempalan ini memang berpotensi konflik. Mereka hadir dengan membawa paham dan gerakan keagamaan yang secara teologis berbeda dengan teologi Ahlussunnah yang dianut kebanyakan umat Islam di Indonesia, dan secara kuantitas mereka minoritas. Dengan perbedaan pandangan seperti itu, maka akan sangat mudah memunculkan peristiwa sosial yang berorientasi destruktif. Oleh karena itu, dibutuhkan suatu desain politik keagamaan yang dapat mengatur "lalu lintas" aliran-aliran keagamaan agar mereka dapat hidup dalam situasi yang kondusif, dengan memperhatikan aspek-aspek dasar dalam teologi Islam.

Problemnya, pendekatan negara dan kelompok agama mainstream dalam menyelesaikan persoalan kelompok sempalan terlalu simplistis. Kelompok Islam mainstream telah merasa puas jika berhasil menyesatkan kelompok sempalan tersebut, tanpa melacak lebih jauh fenomena tersebut. Penyesatan kelompok sempalan dianggap sebagai penyelesaian yang paling efektif. Padahal, pelabelan sesat bagi komunitas tersebut tidak memberi dampak apa-apa terhadap perubahan kelompok tersebut.

Berdasarkan konteks itu, penelitian ini dimaksudkan untuk menggambarkan kostruksi paham Agama Allah agar masyarakat memiliki informasi yang lengkap. Selain itu, penelitian ini menggambarkan pula respon tokoh agama terhadap gerakan keagamaan Paruru sebagai tokoh dibalik "Agama Allah'.

\section{Messianisme; Kunci Lahirnya Komunitas Keagamaan Baru}

Mengapa kelompok-kelompok keagamaan "sempalan" mudah lahir dan memiliki pengikut? Messianisme merupakan salah satu jawabannya. Messianisme adalah suatu pandangan yang mengandaikan munculnya seorang 'messiah' atau penyelamat umat yang mengeluarkan manusia dari kondisi sosial yang sedang mengalami degradasi. Sang messiah selalu memberikan harapan akan kehidupan baru yang lebih layak. Lebih dari itu, Sang Messiah pun menampilkan legitimasi ketuhanan pada dirinya, misalnya sebagai penerima wahyu Tuhan.

Konsep messianisme tidak hanya muncul dalam konteks agama saja, tetapi juga muncul dalam konteks politik. Misalnya munculnya konsep Ratu Adil dan Satrio Piningit dalam konteks politik Indonesia. Kemunculan Ratu Adil dan Satrio Piningit senantiasa ditunggu oleh masyarakat Indonesia untuk mengduarkanbangsaini dari berbagai keterrjurukan. ${ }^{2}$

Messianisme dalam konteks agama merupakan konsep dasar dari kedatangan para nabi. Ketika kehidupan manusia berada dalam keadaan gelap-gulita, kedatangan sang juru selamat senantiasa dinantikan. Messianisme dalam agama Yahudi mengarah pada Nabi Musa. Penindasan Raja Firaun yang sangat berlebihan dan "melampuai" batas toleransi kemanusiaan. Bangsa Yahudi membutuhkan seorang

'Abdurrahman Baidawi. 2003. Sejarah Ateis dalam Islam, LKiS; Jogjakarta.
${ }^{2}$ Misnal Munir. t.t Messianisme dalam Pespektif Sejarah, diakses dari www. jurnal.Jilsafat.ugm.acid tanggal 02 Maret 2009. 
raessias, sang juru selama yang akan memberi mereka kebebasan dan mengembalikan martabat kemanusiaan mereka. Harapan bangsa Yahudi terwujud dengan kedatangan Musa. Kitab Talmud menyebut Musa sebagai savior of Israel (penyelamat Israel). Musa tidak hanya sekedar juru selamat yang membebaskan bangsa Yahudi dari perbudakan, tetapi juga membawa ajaran baru, yaitu agama Yahudi. ${ }^{3}$

Berbeda dengan dua agama sebelumnya, konsep messianisme dalam Islam tidak dialamatkan kepada Nabi Muhammad SAW, tetapi kepada Imam Mahdi. Abdulaziz Abdulhussein Sachedina mengatakan bahwa istilah messianisme dalam konteks Islam seringkali berkaitan dengan gambaran figur masa depan, Imam Mahdi. Imam Mahdi diyakini sebagai pemimpin yang akan bangkit untuk melakukan transformasi sosial. Ia membawa pemeluk Islam ke dalam keyakinan yang benar, dan membebaskan seluruh manusia dari segala macam penindasan. ${ }^{4}$

Konsep Mahdiisme atau messianisme Islam merupakan salah satu faktor epistemologis dari kelahiran aliran-aliran keagamaan "kecir' dalam Islam di Indonesia (dan dunia pada umumnya). Seluruh aliran ini memiliki tokoh sentral yang merupakan pimpinan spiritual yang dianggap memiliki wahyu dan relasi yang sangat dekat dengan Tuhan. Tak jarang pimpinan spiritual ini diklaim sebagai "titisan" Imam Mahdi, perwakilan nabi, sederajat dengan nabi, atau bahkan diklaim sebagai nabi.

\section{PEMBAHASAN}

\section{Siapa Paruru Daeng Tau?}

Paruru Daeng Tau adalah sosok sederhana, bersahaja, dan memiliki tutur kata yang lembut. Ia selalu memanggil orang dengan sebutan "anak". Ia memiliki perawakan yang tinggi tegap, wajah yang lumayan gagah, berambut gonrong bagian pelipis kiri kanan dicukur pendek dan selalu memakai jaket besar kemanapun pergi. Sekilas tidak ada yang aneh di diri Paruru. Usia Paruru masih terbilang muda, sekitar 37 tahun. Paruru lahir di, Kabupaten Takalar pada tahun 1973. Ia lahir dari keluarga petani miskin, karena itu- lah ia tidak sanggup melanjutkan pendidikannya setelah menamatkan sekolah di SMPN 2 Takalar pada medio tahun 1980-an.

Dengan situasi kemiskinan dan pendidikan yang relatif sangat rendah, Paruru sulit mendapatkan pekerjaan. Setamat sekolah ia bekerja sebagai gembala sapi orang di kampungnya. Setelah tumbuh dewasa, Paruru kemudian menjadi tukang becak di Kota Makassar sejak tahun 1990. Hingga akhirnya pada tahun 2000, ia mendapatkan pengalaman spiritual yang sangat dahsyat. Pengalaman spiritual itu mengubah hidupnya dari seorang "buta" agama menjadi penutur agama (meski dengan versi-nya sendiri), menjadi penutur kearifan dan kebijakan yang berorientasi kemanusiaan.

Paruru mengakui bahwa standar pengetahuan agama Islamnya sangat rendah. Ia hanya belajar mengaji di kampung. Itu pun tidak selesai. Hasilnya, Paruru sama sekali tidak mengerti membaca Alquran. Ia tidak pernah sekolah di madrasah, pesantren, atau pengajian manapun. Tetapi, pengalaman spiritual bertemu dengan "Tuhan" yang mengajarinya Alquran menyebabkan ia sedikit demi sedikit mengerti Alquran (meski ketika ia membaca ayat, tajwidnya sangat belepotan, dan sering salah sebut).

Menurutnya, meskipun ia tidak bisa mengaji (membaca Alquran), tetapi ia sangat raj in menjalankan shalat lima waktu, puasa dan bersedekah (kalau ia dapat sedikit rezeki). Hanya haji yang ia tidak laksanakan karena keterbatasan ekonomi. Bahkan ketika kecil, ia pernah bermimpi bertemu dengan Nabi Muhammad sebanyak dua kali. ${ }^{5}$

Sejak mendapatkan pengalaman spiritual tersebut pada tahun 2000, Paruru mulai mengembara ke berbagai daerah. Ia mendatangi semua kelompok-kelompok yang dianggap memiliki ilmu keagamaan. Ia mendatangi gereja-gereja dan berdiskusi soal agama Kristen. Ia mendatangi beberapa kelompok kajian Islam dan memperoleh pengajaran-pengajaran tentang Alquran dan hadits. Ia mendatangi suku Kajang, mendatangi Ambo di Luwu (paham yang dianggap sesat oleh MUI

J. Kalusner. 1979, "The Source and Beginning og the Messianic Idea", dalam Leo Landman (ed), Messianism in the Talmudic Era, KTAV Publishing House Inc., New York., h. 29.

Abdulaziz Abdulhussein Sachedina, 1981. Islamic Messianisme: The Idea of the Mahdi in Twelver Shi 'ism, State university of New York Press, New York. H. 2

Uniknya, ketika menjelaskan tentang pengalaman keagamaan masa lalunya, ia selalu mengatakan: "...dulu, waktu-ku masih Islam". Pernyataan ini menunjukkan bahwa posisi spritualnya saat ini diakuinya sebagai "bukan" Islam lagi, tetapi agama Allah, la mengibaratkan Islam dan agama-agama yang ada sebagai gerbong kereta yang telah penuh sesak manusia. Di dalamnya, tidak ada kasih sayang, tidak ada perhatian kepada orang yang lemah. Karena itu, ia -dengan petunjuk "'Yang Maha Suci" berpindah gerbong ke Agama Allah (wawancara, 01 Pebruari 2010) 
Kabupaten Luwu Utara), mendatangi Ahmadiyah ketika hendak didemo oleh kelompok massa pada tahun 2005, mendatangi komunitas An-Nadzir di Gowa, bahkan ia sempat ke Palu mendatangi seseorang yang mengaku sebagai titisan Bung Karno. Seluruh pengembaraan ini dilakukan berdasarkan bisikan dari alam gaib yang ia sebut Allah Yang Maha Suci.

Meski paham yang dibawanya dianggap sesat oleh tokoh agama, Paruru tidak takut untuk bertemu dengan siapa-pun. Ia malah berharap dapat bertemu ulama yang dapat menjelaskan dan menghilangkan pengaruh roh tersebut dalam dirinyajika memang yang ia alami itu adalah sebuah kesalahan. Baginya, misi spiritual yang dibawanya sesuai dengan semangat agama manapun di dunia ini, karena itu dia berharap bergandengan dengan pemuka agama untuk memperbaiki dunia dari segala bentuk kemurkaan. Bukan untuk berdebat soal siapa yang benar dan siapa yang salah karena baginya itu tidak penting. Yang penting adalah bersama-sama memperbaiki kerukunan antar umat beragama di muka bumi.

Perubahan pada diri Paruru berawal dari pengalaman spiritual yang terjadi padanya pada pertengahan tahun 2000. Suatu pengalaman spiritual yang diakuinya mengejutkan dan mengherankan karena tak terduga sama sekali. Berikut petikan wawancara dengan Paruru:

Jadi kemarin, tahun 2000 terjadi keanehan kepadadiriku ini sebagai hamba yang hina di hadapan Allah, kejadiannya pas bulan haji jadi saya ingat betul itu. Sehabis shalat Magrib, saya berbaring-baring di atas tempat tidur. Tidak tidur, baring-baringy'/'. Tiba-tiba rumahku dan barang-barang yang ada di sekeliling saya kurasahilang. Jadi saya tembus melihat ke langit. Saya lihat langit cerah, banyak bintang yang kumpul. Bintang-bintang bersatu, bergerak dan seperti tali masuk ke dalam kepala saya. Setelah itu, satu per satu atap rumah, dinding muncul kembali. Saya kaget sekali! Saya bangun shalat Isya, turun satu sosok bersinar terang, pake surban, tidak bicara, membelakangi saya seperti mengimami saya, tapi dia tidak bicara-bicara. Setelah ituhilang!. Selesai shalat subuh, kira-kirajam setengah enam, saat itu saya berada di halaman membersihkan, saya dengar ada suara bicara sabbara' ko nak! Saya cari suara itu, kayaknya dari tanah itu! Suara itu selalu bicara sabbara 'ko nak! (sabar, nak). Saya bertanya: apa itu sabar? Dijawab: kalau kau dimarah sama isterimu sabar, kalau kau dapat penghasilan sedikit sabar! Kejadian ini berlangsung selama empat hari. Pada hari berikutnya, sosok itu tidak datang lagi. Saya bertanya-tanya: kemana engkau wahai saudaraku? Adajawaban dalam hati saya: saya ada di dalam dirimu ini! Sejak itu,saya sering berdialog dengan suara hati. Mama-mu (istrinya-pen) di rumah, sering anggap saya gila karena dilihat saya sering bicara sendiri. ... (wawancara 26 Januari 2010)

Keanehan yang dialami oleh Paruru adalah "pintu masuk" menuju alam spiritual yang lebih menantang. Sejak meyakini bahwa dirinya telah menyatu dengan sosok yang datang kepadanya. Ia selalu merasa mendapatkan bimbingan-bimbingan spiritual melalui suara-suara gaib yang sering muncul dari hatinya. Ia diajarkan kesabaran, kecintaan terhadap sesama manusia, dan keberpihakan terhadap orang yang terpinggirkan. beberapa Salah satu misi utama yang sering dianjurkan oleh "suara gaib" tersebut adalah rumbang karama (menghancurkan keramat). Berikut petikan wawancara dengan Paruru:

Sebagian besar belum diterima sembahyangnya dimana-mana keramat dibudayakan, mohon maaf ini merupakan pemberitahuan yg saya terima dari Allah. Jadi pertama waktu itu saya dapat persoalan saya dipanggil lewat gaib saudaraku yang ditaruh di atas gunung kemudian dibikinkan rumah di situ saudarasaudaraku di Takalar saya datang doakan saudarasaudaraku yg ada di keramat itu setelah ziarah kubur penghuni kubur keramat itu mengatakan kepada saya bakar ini rumah nak saya tidak mau lagi kembali ke bumi cukupmi saya panas kepanasan dan hujan kehujanan di tempat ini. Jadi pada saat itu saya doakan saudaraku yang gaib setelah ituhilang dari pandangan mataku pandangan mata batinku kemudian saya bakar itu tempat dan satu desa di situ mau membunuh saya tapi karena ini perintah Allah maka saya jalankan meski saudaraku di situ membenci saya.. Sejak kejadian itu saya mulai berhadapan dengan saudara-saudaraku walaupun saya menyayangi saudaraku yang menyembah keramat tapi karena mereka tidak memahami sampai juga pada waktu itu saya hampir juga dibakar. Saya masih ingat betul kejadian itu saya sembahyang duhur di masjid setelah itu saya ditarik di masjid oleh fanatiknya dan itu bukan salahnya saudaraku dan itu salahku karena sebelumnya saya tidak memberikan pemahaman saya langsung bakar itu keramat sementara di sana mereka meminta kepada keramat itu. Jadi, pada waktu itu saya disiram bensin di pinggir jalan dengan alasan sayamembakar tuhannya saya punya saudara. Saya mau dibunuh tapi dengan izin Allah beliau memadamkan korek dan bilang wahai hambaku berdiri dari tempat itu jalan tapi saya bilang utk apa saya jalan karena saya ingin memberi arahan kepada saudaraku karena mereka belum memahami engkau ya Allah. Kemudian Allah ketika itu menjawab belum waktunya, nanti bermasalah-£o suatu saat nanti kamu akan kembali untuk meluruskan aqidah saudaramu bukan lagi di dalam hatimu. Jadi pada saat 
itu saya berdiri dari tempat dudukku karena saya didudukkan di pinggir jalan mau dibakar, kemudian Allah mengizinkan saya lari pada saat di tengah perjalanan lari saya tidak tahu Allah kemanakan saya, saya lari ke barat dan orang yang memburu ada yang lari ke selatan ada utara. Saya sungguh tidak tahu apaapadi luar jangkauan sayamanusia yang hina di muka bumi ini sampai saya selamat sampai ini hari. ${ }^{6}$

Berdasarkan pada "pernyataan" di atas, Paruru merasa memiliki tugas untuk menyelamatkan para penghuni benda-benda yang dikeramatkan manusia. Roh-roh nenek moyang penghuni kuburan, saukang, dan tempat keramat lainnya sudah lelah berada di tempat itu. Mereka ingin bebas dan kembali kepada Allah. Kedatangan Paruru selain untuk menyelamatkan manusia yang senantiasa menyembah keramat, dan sekaligus menyelematkan roh-roh penghuni keramat yang "kesepian".

Ada hal menarik dari pernyataan ini. Paruru memiliki agenda "pemurnian akidah" dengan perspektif dan cara yang tidak lazim. Perspektif pemurnian selama ini dimiliki oleh gerakan Islam modernis dan kelompokkelompok Wahabian dengan pendekatan rasionalis, yaitu bahwa penyembahan terhadap benda-benda keramat bertentangan dengan rasionalitas, dan bertentangan dengan konsep tauhid Islam. Paruru mendekatinya dengan perspektif yang berbeda. Bagi Paruru, setiap keramat memiliki arwah yang sebenarnya ingin segera ke dunia roh tetapi diikat oleh ritual manusia yang selalu datang kepadanya. Paruru datang dengan membakar keramat untuk membebaskan roh tersebut dari belenggu "penyembahan" manusia. Artinya, Paruru melakukan penghancuran terhadap benda-benda keramat tidak untuk penegasan tauhid tetapi penyelamatan roh yang ada di balik keramat. Produksi berfikir yang dilakukan tetap melalui epistemologi tradisionalis dengan pendekatan yang berbeda, yaitu bahwa dibalik benda memiliki kekuatan gaib, roh, yang dapat diperlakukan dengan cara-cara tertentu, tetapi roh tersebut merasa terkekang dan membutuhkan kebebasan!

Paruru benar-benar mabuk spiritual. Perjalanan spritualnya tidak hanya berhenti pada titik-titik dialog dengan suara-suara gaib serta instruksi-instruksi untuk melakukan misi keagamaan, tetapi juga telah merambah ke wilayah eksistensi Tuhan. Puncaknya pada tahun 2004, ia mengaku dapat bertemu dengan Allah. Paruru menilai pertemuan dengan "Allah" adalah puncak dari spritualitasnya. Sebelum bertemu dengan Allah Yang Maha Tinggi, ia pernah didatangi oleh beberapa sosok yang merupakan penguasa alam semesta yang kesemuanya mengaku Tuhan. Mereka memiliki wajah yang mirip tapi dengan nama yang berbeda. Ada yang bernama Nurun Muhammad (penguasa air), nur Allah Taala (penguasa tanah), Nurun Adam, Allah Taala, Allahu (penguasa bintang), Allah Rasulullah, laa ilaha illallah (lihat struktur ketuhanan). Sosok terakhir ini tidak berdaging dan ia berwarna hitam. Kesemua sosok ini menurut Paruru adalah penguasa-penguasa beberapa elemen alam semesta, mereka adalah bagian dari struktur ketuhanan. Paruru mengatakan tidak ingin menghamba kepada tuhan-tuhan ini karena jika ia membaca alhamdullillah rabbil alaman wa lam yakun lahu kufuan ahad, sosok-sosok ini menghilang. Hingga akhirnya, ia bertemu langsung dengan Allahu Akbar sebagai Tuhan Yang Maha Tinggi.

\section{Inti Ajaran Agama Allah}

Paruru menyebut agama yang dianutnya sebagai Agama Allah yang berbeda dengan Islam, Kristen, Katolik, Hindu, Budha, Konghucu atau agama lain. Tetapi, Paruru sangat meyakini Agama Allah adalah Agama Nabi Adam yang berarti induk dari semua agama yang ada di muka bumi ini. Ajaran Allah memuat ajaran tentang 1) assasi (kesaksian sebagai hamba). Kalimat persaksian dalam agama Allah berbunyi: mannasa tena karaeng kusomba, passangadinna I katteji Karaeng Malompoa (sungguh, tidak ada yang kusembah selain hanya engkau, Tuhan Yang MahaAgung). Kalimat ini dibaca pada saat melakukan annyompa (penyembahan). 2) hnynyompa (penyembahan). Penyembahan atau annyompa dalam Agama Allah kadang disebut angngolo (menghadap). Arah penghadapan ke Selatan. Proses ini dilakukan dua kali sehari semalam, satu kali siang hari dan satu kali pada malam hari. Tidak ada jam khusus pelaksanaan anyompa. Biasanya Paruru melakukannya sesuai dengan kondisi dimana ia merasa longgar atau telah lepas dari kesibukan. Selama ini, ia sering melakukan ritual pada pukul 01.30 di siang hari dan pukul 20.30 di malam hari karena pada jam-jam tersebut ia merasa longgar. Gerakan annyompa hanya dua yaitu ammempo (duduk bersimpuh) dan sujju (sujud). Duduk bersimpuh dilakukan sambil menundukkan kepala sembari mengangkat tangan melewati kepala. Kedua telapak tangan dirapatkan. Pola'gerakan ini menyerupai

\footnotetext{
‘ Pernyataan disampaikan di depan forum dialog keagamaan di Kantor Departemen Agama Kota Makassar, tanggal 06 Januari 2010.
} 
penghormatan seorang hamba pada raja-raja masa lalu. Sedangkan gerakan sujud merryerupai gerakan sujud dalam shalat. Gerakan ini disertai dengan bacaan dalam Bahasa Makassar. 3) Assingai-ngai (kasih sayang). Paruru meyakini bahwa semua manusia berasal dari sumber yang sama yaitu nabi Adam, dan semua keyakinan berasal dari sumber yang sama yaitu Allah. Berdasarkan itu, manusia di muka bumi tidak layak untuk saling berperang atas dasar keyakinan. Tidak boleh saling menuding satu sama lain, karena semuanya sama. Manusia harus hidup saling mengasihi, menyayangi, tidak menggunakan kekerasan dalam hidup. 4) Assidakka (bersedekah). Agama Allah menurut Paruru sangat menekankan pentingnya sedekah. Sedekah sebagaijembatan penghubung antar manusia yang kaya dan miskin. Sedekah juga dapat mendekatkan orang-orang kaya kepada Allah yang berada di "kalangan" orang-orang miskin. Besaran sedekah minimal sepuluh persen, atau dalam Bahasa Paruru "seribu rupiahnya dari sepuluh ribu rupiah". Sedekah tidak memiliki ukuran dan waktu (haul dan nisab dalam Islam). Kapan saja memiliki harta, saat itu pula sedekah diharuskan.

Selain keempat inti ajaran Agama Allah, Parurujuga sangat meyakini kalau dirinya dapat bertemu Allah, Sang Maha Pencipta dengan mata kepala. Paruru menantang siapa saja yang tidak yakin bahwa yang ditemuinya adalah benar-benar Allah, untuk bersama-sama melihat sosok yang disebut Allah tersebut. Keseluruhan konstruksi Agama Allah menurut Paruru adalah "perintah Allah" yang diterima secara langsung, baik secara sadar maupun dalam keadaan mimpi. Logika yang dimainkan oleh Paruru sangat sederhana. Kejadian yang ia alami ini adalah "kehendak Tuhan" bukan kehendaknya sebagai manusia atau hamba. Ia terpilih bukan meminta. Bahkan ia pun terheran-heran mendapatkan "berkah" itu karena merasa tidak layak. Tuhan-lah yang berkehendak atau mengambil inisiatif untuk menemui hamba-Nya. Kun $f a$ yakun, jika Tuhan berkehendak, apa yang tidak bisa terjadi? Kira-kira argumentasi seperti itu yang sedangkan dimainkan oleh Paruru.

Lebih jauh menurut Paruru adalah penguasa Alam semesta tidak hanya satu, tetapi berbentuk lembaga Ketuhananyang dipimpin oleh "Allahu Akbar" sebagai Tuhan tertinggi. Konsep ketuhanan dalam perspektif Paruru adalah banyak tuhan dan memiliki struktur. Tuhan ada di semua kekuatan alam, ada di bulan, matahari, bintang, laut, air, tanah, api, bayangan, langit, dan bumi. Di atas semua tuhan-tuhan kecil ini-lah bersemayam Allahu Akbar, Allah yang mengeluarkan
Adam dari Surga, Allah Yang Maha Suci. Sekilas, konsep ketuhanan Paruru mirip dengan konsep ketuhanan agama -agama lokal. Misalnya konsep ketuhanan Tolotang. Tolotang meyakini bahwa dewa Tertinggi adalah Dewata Seuwae. Di bawah Dewata Seuwae, ada beberapa dewa yang menguasai elemenelemen alam seperti dewa uwae, dewa tana, dewa anging, dewa langi', dewa lino.

\section{SILSILAH KETUHANAN MENURUT PARURU}

ALLAHU AKBAR

RASULULLAH

LAILAHAILLALLAH

MUHAMMAD RASULULLAH

ALLAHU

ALLAH

$\dot{1}$

ALLAH TA'ALA

$\dot{1}$

NURUNGADAM

NURUNG ALLAHU

NURUNG ALLAH

1

NURUNG ALLAH TA'ALA

NURUNG MUHAMMAD

ALLAHU RASULULLAH

I

MA'NASSATAU

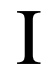

RUPATAU (NABI ADAM)

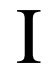

Silsilah ketuhanan versi Paruru adalah struktur kekuasaan yang menguasai alam semesta di bawah "koordinasi" Allahu Akbar sebagai penguasa tertinggi. 
Allahu Akbar menurut Paruru tidak berhubungan langsung dengan alam semesta. Ia menempatkan "bawahan-bawahannya" untuk menguasai struktur alam seperti langit, bumi, tanah, air, udara dan sebagainya. Bawahan-bawahan ini-lah yang selama ini berhubungan dengan manusia.' Bahkan, Allahu Akbar tidak lagi "bekerja" setelah Ia mengeluarkan Nabi Adam dari surga. Jadi yang berhubungan dengan nabi-nabi, selain Adam adalah tuhan-tuhan yang berada di bawah Allahu Akbar. Ini-lah yang menyebabkan syariat berbeda-beda antar satu nabi dengan nabi lainnya.

Pertemuan dengan "Allahu Akbar" ini merupakan puncak spiritualitas Paruru. Ia meyakini bahwa Allahu Akbar inilah Tuhan semesta alam, Tuhan yang mengeluarkan Adam dari surga. Karena itu-lah, ia merelakan diri menjadi hamba (berbeda kepada tuhantuhan sebelumnya) Allahu Akbar ini-lah kemudian yang memberi bimbingan-bimbingan dan pengajaranpengajaran tentang kearifan hidup, yang uniknya selalu didialogkan dalam Bahasa Makassar, bukan Bahasa Arab ! Allahu Akbar ini-lah yang menurut Paruru memberinya "wahyu" untuk melaksanakan Agama Allah $^{8}$ dan tata cara penyembahannya. "dengan bantuan la ilaha ilia llaha, say a melihat (Allah) dengan mata kepala" (wawancara dengan Paruru tanggal 29 Januari 2010).

Intimitas relasi antara Allah dan hamba dalam kasus Paruru menjadi unik karena muncul berdasarkan pengalaman spiritual yang tiba-tiba, tidak melalui perjuangan panjang seperti kaum sufi yang mendapatkan ilmu makrifat melalui usaha yang sungguh-sungguh dengan harus melewati maqammaqam atau tangga-tangga spiritual tertentu. Berbeda tentu saja dengan penyatuan antara Tuhan dan hamba versi Al-Hallaj yang terkenal dengan adagium wihdatid wujud-nya. Ilmu yang didapatkan Al-Hallaj melalui upaya pengasingan diri dan ritual yang sangat panjang. Atau ilmu manunggaling kawolu-gusti- nya Siti Jenar yang juga diperoleh melalui perenungan dan perjalanan spiritual yang "rumit".
Kelebihan Paruru adalah karena ia terbuka untuk berdialog dengan siapa saja. Bahkan dengan tegas ia ingin menemui ulama yang mampu "menjelaskan" secara gamblang kesalahannya, jika ia memang dianggap salah. Paruru tidak menutup diri dari kemungkinan terjadinya dialog dengan para ulama. Ini karena Paruru meyakini bahwa apa yang dia peroleh adalah kebenaran dari Tuhan.

Gerakan Paruru sejauh ini masih bersifat personal. Instruksi spiritual yang diperoleh tidak mewajibkan Paruru untuk menyebarkan paham keagamaannya. Tetapi, si stem pewahyuan dalam konteks keagamaan Paruru bersifat "cair", berlangsung terus menerus dan karena itu sangat mudah mengalami perubahan. Perilaku keagamaannya sangat terpengaruh pada "perintah" spiritual yang sangat aksidental dan temporer, bukan landasan tertulis yang baku. Akibatnya, bisa saja perintah untuk menyebarkan Agama Allah akan datang suatu waktu. Jika itu terjadi, maka kemungkinan terjadinya titik singgung antara Paruru dan kelompok Islam mainstream akan mudah terjadi. Ini karena keseluruhan konstruksi pemahaman keagamaan Agama Allah sangat jauh berbeda dengan apa yang dipahami oleh kelompok Islam mainstream, mulai dari sistem teologis hingga sistem syariatnya. Titik ini perlu mendapatkan perhatian lebih dari pihak pemerintah dan instansi yang terkait.

Jumlah pengikut Paruru tidak dapat diketahui lebih detil karena gerakan Paruru bersifat tidak tetap. Tidak ada komunitas atau jamaah yang dibangun. Ia hanya membangun pertemanan dengan orang-orang yang dapat memahami dirinya. Tetapi, melihat mobilitas Paruru dari tempat satu ke tempat yang lainnya, ia berpotensi mempengaruhi orang-orang yang selama ini dekat dengan dunia spiritual dan orang-orang miskin yang butuh panutan.

\section{Respon Tokoh Agama}

Inti persoalan dalam kasus Paruru adalah keyakinannya dapat bertemu dengan Allah dan memperoleh "bisikan" spiritual secara terus menerus

\footnotetext{
Nama-nama dalam struktur ketuhanan adalah nama-nama Tuhan. Rasulullah, Muhammad Rasulullah bukan-lah nama Nabi Muhammad dalam ajaran Islam tetapi nama Tuhan. Menurut Paruru, tuhan-tuhan ini di dalam Alquran dianggap sebagai malaikat. Padahal bukan malaikat, melainkan tuhan-tuhan atau dewa (wawancara 30 Januari 2010 ).

s Istilah agama Allah muncul sebagai jawaban Paruru atas pertanyaan peserta dialog yang dilaksanakan Kandepag Kota Makassar tanggal 06 Januari 2010 tentang apa agama Paruru? Secara sederhana, Paruru menjelaskan bahwa Agama Allah sesungguhnya memiliki basis pada nash Alquran sebagaimana yang diajarkan oleh "Yang Maha Suci", yaitu pada surat An-Nasr ayat 1 dan 2: jika datang pertolongan Allah, Kamu akan melihat manusia berbondong-bondong masuk ke dalam agama Allah (din Allah). . . . . Kata "agama Allah" dalam surah ini adalah landasan Agama Allah. Secara eksplisit, Paruru mengakui bahwa agama Islam dan agama Allah sangat dekat, meski secara syariat (tata cara penyembahan) tidak sama.
} 
yang kemudian melahirkan Agama Allah. Keyakinan dapat "bertemu dan melihat" Allah dalam teologi Islam mainstream memang dimungkinkan, meski hal ini menjadi perdebatan panjang antara beberapa kelompok.

Menurut AGH. Baharuddin HS (Rois Syuriah PC. NU Kota Makassar), Islam mengenal dua istilah dalam kemungkinan "melihat dan bertemu" dengan Tuhan, yaitu nazhirah dan basyirah. Nazhirah, berarti melihat secara terang benderang dengan mata telanjang. Melihat Tuhan seperti melihat bulan. Sedangkan bashirah, berarti pertemuan/melihat dengan menggunakan mata hati. Melihat Tuhan dalam konteks nazhirah dapat terjadi di akhirat dan itu dinyatakan dalam Alquran dan hadits Nabi. Sedangkan "melihat" Tuhan dalam konteks basyirah dapat terjadi di dunia khususnya ketika melakukan shalat (khusyu'), tafakkur atau sedang kontemplasi. Para sufi sering melakukan hal ini (wawancara, 29 Januari 2010).

AGH Muhammad Ahmad (Ketua MUI Kota Makassar) secara tegas mengatakan bahwa sosok yang datang kepada Paruru adalah bukan Allah, tetapi setaa Beliau melihat Paruru sebagai korban dari mahluk halus. Mahluk halus datang dalam bentukyang "suci", pura-pura mengajarkan kebaikan tetapi secara perlahan-lahan membelokkan akidah Paruru. Itu terlihat jelas dari "instruksi" roh untuk menghilangkan teks "asyhadu anna muhammadan rasulullah" dalam kalimat syahadat, tidak lagi melaksanakan shalat lima waktu tetapi dua waktu saja dengan format gerakan yang hanya menunduk dan sujud, menggunakan bahasa lokal dalam beribadah, dan tidak puasa. Reduksi ini merupakan "pembelotan" dari teologi mainstream. Dan karena itu, yang datang ke Paruru adalah setan! (pernyataan disampaikan dalam pertemuan di Kantor Kadepag Kota Makassar, tanggal 06 Januari 2010)

Pendapat serupa disampaikan oleh Prof. Arifuddin Ahmad, Guru Besar UIN Alauddin yang turut hadir dalam acara dialog keagamaan tersebut. Ia mengatakan bahwa sosok yang hadir ke dalam "imajinasi spiritual" Paruru adalah makhluk halus yang bertujuanjahat. Indikatornya, tentu saja adalah pembelokan arah teologi dan praktik ritual Islam yang menjadi agama anutan Paruru selama ini. Paruru-lanjutnya- harus melakukan perlawanan terhadap roh tersebut agar tidak tersesat lebih jauh.
Kedua tokoh agama ini melihat kasus Paruru dengan pendekatan normatif Islam, pendekatan syariat! Implikasinya adalah keseluruhan pengalaman spiritual Paruru adalah sebuah penyimpangan akidah, dan subversif terhadap syariat Islam. Karena itu Paruru sesat! Keduanya meyakini bahwa tidak mungkin Tuhan melakukan revisi besar-besaran terhadap pakem agama yang telah diturunkannya secara sempurna, yaitu Islam.

\section{Memandang Kasus Paruru dengan Bijak}

Melihat kasus Paruru dengan perspektif syariat atau fiqhi, memang akan membawa kita ke dalam pembacaan hitam dan putih. Secara syariat (Islam), seluruh konstruksi agama Allah versi Paruru adalah menyimpang atau paling tidak telah keluar dari ajaran Islam. Paruru tidak puasa, menyembah kepada Allah tidak dengan model shalat, dan yakin dapat bertemu dengan Allah adalah tindakan yang "tidak sesuai" dengan Syariat Islam. Peneliti setuju bahwa dalam konteks ini, Paruru telah keluar dari pakem Syariat Islam. Dan menariknya, Paruru sendiri secara tegas mengakui kalau dirinya bukan Islam lagi, tetapi adalah penganut agama Allah.'

Kajian psikologi agama mengkategorikan kasus yang dialami oleh Paruru sebagai bagian dari klenik yang merupakan salah satu bentuk penyimpangan agama. Aliran klenik sebagai bagian dari bentuk tingkah laku keagamaan yang menyimpang akan senantiasa muncul dalam setiap masyarakat, apapun latar belakang kepercayaannya. Aliran klenik seperti ini terkadang sangat kuat mempengaruhi mereka yang mempercayainya sehingga menolak pengaruh dari manapun. Seperti yang dikatakan Richard Fenn dalam kasus perang Vietnam. Seorang dukun menolak untuk melatih tenaga medis militer Amerika. Penolakan ini menurut si dukun adalah didasarkan atas bisikan spiritual (wangsit) dari agama yang dianutnya. ${ }^{10}$

Kajian psikologi agama menempatkan penyimpangan agama sebagai penyimpangan kejiwaan yang didorong dari rasa frustasi terhadap situasi sosial yang sedang kacau, kekosongan spiritual, dan penderitaan. Perspektif ini -jika diletakkan dalam melihat kasus Paruru bisa jadi benar adanya? Paruru tidak memiliki latar belakang keagamaan yang kuat, tidak bisa mengaji

\footnotetext{
' Pengakuan tentang dirinya tidak Islam lagi telah disampaikan pada dialog di Kantor Departemen Agama pada tanggal 06 Januari 2010, dan diulangi lagi pada saat wawancara dengan peneliti pada tanggal 25 Januari 2010 .

${ }^{10}$ Tetapi menurut Fenn, penolakan ini lebih bersifat psikologis ketimbang agama. Lihat lebih jauh, Meredith B. Mc Guire. 1981. Religion: The Social Context. California: Wadworth, Inc., h. 250.
} 
Allahu Akbar menurut Paruru tidak berhubungan langsung dengan alam semesta. Ia menempatkan "bawahan-bawahannya" untuk menguasai struktur alam seperti langit, bumi, tanah, air, udara dan sebagainya. Bawahan-bawahan ini-lah yang selama ini berhubungan dengan manusia.' Bahkan, Allahu Akbar tidak lagi "bekerja" setelah Ia mengeluarkan Nabi Adam dari surga. Jadi yang berhubungan dengan nabi-nabi, selain Adam adalah tuhan-tuhan yang berada di bawah Allahu Akbar. Ini-lah yang menyebabkan syariat berbeda-beda antar satu nabi dengan nabi lainnya.

Pertemuan dengan "Allahu Akbar" ini merupakan puncak spiritualitas Paruru. Ia meyakini bahwa Allahu Akbar inilah Tuhan semesta alam, Tuhan yang mengeluarkan Adam dari surga. Karena itu-lah, ia merelakan diri menjadi hamba (berbeda kepada tuhantuhan sebelumnya) Allahu Akbar ini-lah kemudian yang memberi bimbingan-bimbingan dan pengajaranpengajaran tentang kearifan hidup, yang uniknya selalu didialogkan dalam Bahasa Makassar, bukan Bahasa Arab ! Allahu Akbar ini-lah yang menurut Paruru memberinya "wahyu" untuk melaksanakan Agama Allah $^{8}$ dan tata cara penyembahannya. "dengan bantuan la ilaha ilia llaha, saya melihat (Allah) dengan mata kepala" (wawancara dengan Paruru tanggal 29 Januari 2010).

Intimitas relasi antara Allah dan hamba dalam kasus Paruru menjadi unik karena muncul berdasarkan pengalaman spiritual yang tiba-tiba, tidak melalui perjuangan panjang seperti kaum sufi yang mendapatkan ilmu makrifat melalui usaha yang sungguh-sungguh dengan harus melewati maqammaqam atau tangga-tangga spiritual tertentu. Berbeda tentu saja dengan penyatuan antara Tuhan dan hamba versi Al-Hallaj yang terkenal dengan adagium wihdatul wujud-nya. Ilmu yang didapatkan Al-Hallaj melalui upaya pengasingan diri dan ritual yang sangat panjang. Atau ilmu manunggaling kawolu-gusti- nya Siti Jenar yang juga diperoleh melalui perenungan dan perjalanan spiritual yang "rumit".
Kelebihan Paruru adalah karena ia terbuka untuk berdialog dengan siapa saja. Bahkan dengan tegas ia ingin menemui ulama yang mampu "menjelaskan" secara gamblang kesalahannya, jika ia memang dianggap salah. Paruru tidak menutup diri dari kemungkinan terjadinya dialog dengan para ulama. Ini karena Paruru meyakini bahwa apa yang dia peroleh adalah kebenaran dari Tuhan.

Gerakan Paruru sejauh ini masih bersifat personal. Instruksi spiritual yang diperoleh tidak mewajibkan Paruru untuk menyebarkan paham keagamaannya. Tetapi, sistem pewahyuan dalam konteks keagamaan Paruru bersifat "cair", berlangsung terus menerus dan karena itu sangat mudah mengalami perubahan. Perilaku keagamaannya sangat terpengaruh pada "perintah" spiritual yang sangat aksidental dan temporer, bukan landasan tertulis yang baku. Akibatnya, bisa saja perintah untuk menyebarkan Agama Allah akan datang suatu waktu. Jika itu terjadi, maka kemungkinan terjadinya titik singgung antara Paruru dan kelompok Islam mainstream akan mudah terjadi. Ini karena keseluruhan konstruksi pemahaman keagamaan Agama Allah sangat jauh berbeda dengan apa yang dipahami oleh kelompok Islam mainstream, mulai dari sistem teologis hingga sistem syariatnya. Titik ini perlu mendapatkan perhatian lebih dari pihak pemerintah dan instansi yang terkait.

Jumlah pengikut Paruru tidak dapat diketahui lebih detil karena gerakan Paruru bersifat tidak tetap. Tidak ada komunitas atau jamaah yang dibangun. Ia hanya membangun pertemanan dengan orang-orang yang dapat memahami dirinya. Tetapi, melihat mobilitas Paruru dari tempat satu ke tempat yang lainnya, ia berpotensi mempengaruhi orang-orang yang selama ini dekat dengan dunia spiritual dan orang-orang miskin yang butuh panutan.

\section{Respon Tokoh Agama}

Inti persoalan dalam kasus Paruru adalah keyakinannya dapat bertemu dengan Allah dan memperoleh "bisikan" spiritual secara terus menerus

\footnotetext{
Nama-nama dalam struktur ketuhanan adalah nama-nama Tuhan. Rasulullah, Muhammad Rasulullah bukan-lah nama Nabi Muhammad dalam ajaran Islam tetapi nama Tuhan. Menurut Paruru, tuhan-tuhan ini di dalam Alquran dianggap sebagai malaikat. Padahal bukan malaikat, melainkan tuhan-tuhan atau dewa (wawancara 30 Januari 2010).

Istilah agama Allah muncul sebagai jawaban Paruru atas pertanyaan peserta dialog yang dilaksanakan Kandepag Kota Makassar tanggal 06 Januari 2010 tentang apa agama Paruru? Secara sederhana, Paruru menjelaskan bahwa Agama Allah sesungguhnya memiliki basis pada nash Alquran sebagaimana yang diajarkan oleh "Yang Maha Suci", yaitu pada surat An-Nasr ayat 1 dan 2: jika datang pertolongan Allah, Kama akan melihat manusia berbondong-bondong masuk ke dalam agama Allah (din Allah). . . . . Kata "agama Allah" dalam surah ini adalah landasan Agama Allah. Secara eksplisit, Paruru mengakui bahwa agama Islam dan agama Allah sangat dekat, meski secara syariat (tata cara penyembahan) tidak sama.
} 
yang kemudian melahirkan Agama Allah. Keyakinan dapat "bertemu dan melihat" Allah dalam teologi Islam mainstream memang dimungkinkan, meski hal ini menjadi perdebatan panjang antara beberapa kelompok.

Menurut AGH. Baharuddin HS (Rois Syuriah PC. NU Kota Makassar), Islam mengenal dua istilah dalam kemungkinan "melihat dan bertemu" dengan Tuhan, yaitu nazhirah dan basyirah. Nazhirah, berarti melihat secara terang benderang dengan mata telanjang. Melihat Tuhan seperti melihat bulan. Sedangkan bashirah, berarti pertemuan/melihat dengan menggunakan mata hati. Melihat Tuhan dalam konteks nazhirah dapat terjadi di akhirat dan itu dinyatakan dalam Alquran dan hadits Nabi. Sedangkan "melihat" Tuhan dalam konteks basyirah dapat terjadi di dunia khususnya ketika melakukan shalat (khusyu'), tafakkur atau sedang kontemplasi. Para sufi sering melakukan hal ini (wawancara, 29 Januari 2010).

AGH Muhammad Ahmad (Ketua MUI Kota Makassar) secara tegas mengatakan bahwa sosok yang datang kepada Paruru adalah bukan Allah, tetapi setan. Beliau melihat Paruru sebagai korban dari mahluk halus. Mahluk halus datang dalam bentuk yang "suci", pura-pura mengajarkan kebaikan tetapi secara perlahan-Iahan membelokkan akidah Paruru. Itu terlihat jelas dari "instruksi" roh untuk menghilangkan teks "asyhadu anna muhammadan rasulullaW dalam kalimat syahadat, tidak lagi melaksanakan shalat lima waktu tetapi dua waktu saja dengan format gerakan yang hanya menunduk dan sujud, menggunakan bahasa lokal dalam beribadah, dan tidak puasa. Reduksi ini merupakan "pembelotan" dari teologi mainstream. Dan karena itu, yang datang ke Paruru adalah setan! (pernyataan disampaikan dalam pertemuan di Kantor Kadepag Kota Makassar, tanggal 06 Januari 2010)

Pendapat serupa disampaikan oleh Prof. Arifuddin Ahmad, Guru BesarlJTNAlaud<dmyangturut hadir dalam acara dialog keagamaan tersebut. Ia mengatakan bahwa sosok yang hadir ke dalam "imajinasi spiritual" Paruru adalah makhluk halus yang bertujuan jahat. Indikatornya, tentu saja adalah pembelokan arah teologi dan praktik ritual Islam yang menjadi agama anutan Paruru selama ini. Paruru-lanjutnya- harus melakukan perlawanan terhadap roh tersebut agar tidak tersesat lebih jauh.
Kedua tokoh agama ini melihat kasus Paruru dengan pendekatan normatif Islam, pendekatan syariat! Implikasinya adalah keseluruhan pengalaman spiritual Paruru adalah sebuah penyimpangan akidah, dan subversif terhadap syariat Islam. Karena itu Paruru sesat! Keduanya meyakini bahwa tidak mungkin Tuhan melakukan revisi besar-besaran terhadap pakem agama yang telah diturunkannya secara sempurna, yaitu Islam.

\section{Memandang Kasus Paruru dengan Bijak}

Melihat kasus Paruru dengan perspektif syariat atau fiqhi, memang akan membawa kita ke dalam pembacaan hitam dan putih. Secara syariat (Islam), seluruh konstruksi agama Allah versi Paruru adalah menyimpang atau paling tidak telah keluar dari ajaran Islam. Paruru tidak puasa, menyembah kepada Allah tidak dengan model shalat, dan yakin dapat bertemu dengan Allah adalah tindakan yang "tidak sesuai" dengan Syariat Islam. Peneliti setuju bahwa dalam konteks ini, Paruru telah keluar dari pakem Syariat Islam. Dan menariknya, Paruru sendiri secara tegas mengakui kalau dirinya bukan Islam lagi, tetapi adalah penganut agama Allah.

Kajian psikologi agama mengkategorikan kasus yang dialami oleh Paruru sebagai bagian dari klenik yang merupakan salah satu bentuk penyimpangan agama. Aliran klenik sebagai bagian dari bentuk tingkah laku keagamaan yang menyimpang akan senantiasa muncul dalam setiap masyarakat, apapun latar belakang kepercayaannya. Aliran klenik seperti ini terkadang sangat kuat mempengaruhi mereka yang mempercayainya sehingga menolak pengaruh dari manapun. Seperti yang dikatakan Richard Fenn dalam kasus perang Vietnam. Seorang dukun menolak untuk melatih tenaga medis militer Amerika. Penolakan ini menurut si dukun adalah didasarkan atas bisikan spiritual (wangsit) dari agama yang dianutnya. ${ }^{10}$

Kajian psikologi agama menempatkan penyimpangan agama sebagai penyimpangan kejiwaan yang didorong dari rasa frustasi terhadap situasi sosial yang sedang kacau, kekosongan spiritual, dan penderitaan. Perspektif ini -jika diletakkan dalam melihat kasus Paruru bisa jadi benar adanya? Paruru tidak memiliki latar belakang keagamaan yang kuat, tidak bisa mengaji

\footnotetext{
Pengakuan tentang dirinya tidak Islam lagi telah disampaikan pada dialog di Kantor Departemen Agama pada tanggal 06 Januari 2010, dan diulangi lagi pada saat wawancara dengan peneliti pada tanggal 25 Januari 2010.

${ }^{10}$ Tetapi menurut Fenn, penolakan ini lebih bersifat psikologis ketimbang agama. Lihat lebih jauh, Meredith B. Mc Guire. 1981. Religion: The Social Context. California: Wadworth, Inc., h. 250.
} 
dengan baik, ia orang miskin, dan Paruru selalu melakukan kritik terhadap ketidakadilan atas orang miskin, kritik terhadap ketidakpedulian negara terhadap hak-hak orang miskin, dan menyatakan misi agama Allah untuk melakukan kasih sayang dan keadilan kepada orang-orang miskin. Persoalannya kemudian, bagaimana psikologi agama melihat "pengakuan" Paruru yang dapat bertemu dengan Tuhan? bagaimana melihat perubahan kemampuan Paruru dari seseorang yang tidak mengerti apa-apa menjadi sangat mengerti apaapa? Apakah bisikan spiritual hanya bersifat kamuflase, sebagai topeng dari jeritan-jeritan hatinya selama ini?

Kasus Paruru "mungkin" menarik didiskusikan dalam kerangka perspektif sufistik. Pendekatan sufistik memberi ruang yang dinamis, tidak hitam-putih, dan tidak tendensius dalam melihat kasus spritualisme yang "nyeleneh" seperti yang dialami Paruru. Isu spiritual yang dikatakan Paruru seperti bertemu dengan Tuhan, mengembara ke alam spritual, adalah hal lumrah yang sering dibicarakan oleh kaum sufi. Bahkanpertemuan, dan penyatuan dengan Tuhan adalah cita-cita tertinggi kaum sufi. Tuhan bagi kaum sufi sangat ramah, dan mudah ditemui asal mengerti jalannya. Berbeda tentu saja, dengan logikan fiqhi yang selalu membangun "jarak" antara Tuhan dan hamba melalui mekanisme penyembahan yang prosedural dan rigid. Kaum sufi meyakini bahwa Tuhan bisa ditemui di dunia dan akhirat, seperti yang dikatakan Ibnu Rajab Al-Hanbali:

Untuk sampai bertemu kepada Allah ada dua cara salah satunya di dunia, dan kedua di akhirat nanti. Adapun untuk bertemu Allah di dunia adalah bahwa hati bisa sampai ke tingkat ma'rifat (mengetahui) Dia. Jika hati mengetahui-Nya, maka dia akan senang kepada-Nya, lunak dan tunduk pada-Nya, maka hati akan merasa dekat dengan-Nya dan akan menerima sesuai seruanNya. Sebagaimanaterungkap dalam atear sahabat: "Hai anak Adam! Carilah Aku, maka kamu akan menemukan$\mathrm{Ku}$, maka kamu dapat menemukan segalanya. Dan jika Aku tidak ketemu kamu, maka kamu akan kehilangan segalanya."

Tema sentral pembicaraan dalam sufisme adalah Tuhan. Cinta, pemisahan diri dan penyatuan denganNya. Junaid Al-Baghdadi (bapak sufisme ortodoks, yang menjadi anutan sufisme kaum sunni bersama Imam Al-Gazali) mendefinisikan sufisme sebagai "menjadi sahabat Tuhan tanpa alat tambahan' atau 'duduk dalam kehadiran Tuhan tanpa pemeliharaan". Para sufi menurut Dhun-Nun adalah mereka yang cintanya kepada Tuhan melebihi segalanya sebagaimana cinta Tuhan kepada mereka yang melebihi segalanya". Oleh karena itu, corak yang lebih kentara dalam tradisi pemikiran sufisme adalah "sufisme bermakna bahwa Tuhan seharusnya memerintahkan-mu membunuh dirimu sendiri supaya kamu hidup dalam diri Tuhan". Sufisme berarti penghentian rasa keduniawian, ruang-kedirian, pemisahan diri dari semua makhluk ciptaan, penyangkalan terhadap diri dan menghadapkan diri kepada Tuhan. ${ }^{12}$

Sufisme selalu menghadirkan kejutan-kejutan spritual melalui bahasa-bahasa yang bersastra, penuh makna, dan sub-versif. Ia kadang-kadang muncul di luar kebiasaan manusia berbicara atau bertutur, sehingga kadang-kadang dipahami sebagai kegilaan dan ketidakmasuk akalan. Ingat! Hampir semua sufi yang hidup di abad keemasan Islam selalu dianggap gila dan bid'ah. Bahkan Syekh Abdul Kadir Jaelaini, sufi yang normal sekalipun dianggap gila. Para sufisme sangat akrab dengan segala bentuk dunia spiritual, akrab dengan Tuhan, hingga akhirnya ia melebur dan menyatu dengan Tuhan seperti pernyataan dari Abu YazidAl-Bushtami, seorang sufi:

Tuhan telah mengangkat dan menempatkan aku sebelum Dia, dan berkata kepadaku: "Hai Abu Yazid, sesungguhnya ciptaanku rindu berjumpa dengan engkau". Dan Aku berkata: "Hiasi aku dengan keesaan-Mu, sehingga bila makhluk-makhluk-Mu melihatku, mereka akan berkata: Kami telah melihat Engkau (yakni Tuhan) dan Engkau adalah itu. Meskipun Abu Yazid tidak ada di situ. ${ }^{13}$

Zachner mengakui di ucapan Abu Yazid ada frase "Engkau adalah itu" (thou are that) yang sulit dipahami dalam konteks gramatika ini. Karena tidak dapat dipahami, Nicholson lebih suka menerjemahkan dengan: "dan hanya Engkau yang di situ, bukan aku". Fariduddin Al-Attar menerjemahkan secara bebas frase Abu Yazid dengan: "Hiasi aku dengan keesaan$\mathrm{Mu}$ sehingga ketika makhluk-makhluk-Mu melihatku dan memandang hasil perbuatanku, niscaya mereka akan melihat sang Pencipta". ${ }^{14}$

"Lihat Al-Hafidz Ibn Rajab Al-Hanbali. 2000. Pengembaraan Spritual; Kajian Reflektif Dunia Sufi. Diterjemahkan dari buku asli yang berjudul "Al-Mahajjah Fii Sairi Ad-Duljah". Jakarta: Pustaka Azzam., h. 103.

${ }^{12}$ Lihat R.C. Zachner. 2004. Mislisisme Hindu-Muslim. Jogjakarta: LKiS., h. 7.

${ }_{13}$ ibid, h. 118. Zachner mengutip kalimat Abu Yazid dari Kitab Assarraj.

is ibid, h. 119. 
Selain kesulitan pemahaman gramatikal seperti yang diperdebatkan Zachner, Nicholson, dan Al-Attar, kalimat Abu Yazid terasa sangat tidak masuk akal (dalam konteks bahasa syariat atau bahasa fiqhi). Bagaimana mungkin seorang hamba dapat duduk di belakang Tuhan, dan berbicara kepadanya? Bukankah Tuhan tidak bertempat? Tetapi itu-lah dunia sufi. Dunia yang sangat dinamis dan sangat fleksibel terhadap "dunia kegaiban". Dunia gaib yang metafisis, rumit, dan tak tersentuh akal, oleh sufi dibuat dalam bentuk penuturan kata-kata yang mencengangkan dan dengan makna yang juga kadang-kadang sulit dipahami secara linear. Tuhan yang jauh dalam "kata" dan "psikologi" manusia, diletakkan sedekat mungkin, hingga menyatu dengan manusia! Alam semesta yang sedemikian luas oleh dunia sufi dipahami sebagai ruang kecil yang bisa dijelajahi dalam sehari atau semalam saja. Oleh karena itu, peristiwa spiritual seperti isra' mi'raj bagi kaum sufi adalah peristiwa normal yang dapat dilakukan oleh siapapun yang mendekatkan diri kepada Allah.

Membicarakan kasus Paruru dengan pendekatan sufisme memberi dua kemungkinan perspektif. Pertama, belum tentu Paruru sedang tersesat! Atau paling tidak, tesis dua tokoh agama di atas yang mengklaim Paruru sedang bertemu setan belum tentu benar. Boleh jadi, Paruru sedang mengalami proses emanasi spiritual, penyatuan dengan alam gaib, dan "bertemu" secara imajiner dengan Sang Pencipta, seperti yang dialami dan dirasakan oleh para sufi. Kedua, atau boleh jadi Paruru sedang mengalami guncangan spiritual yang begitu dahsyat, ia sedang dalam kebingungan dan membutuhkan kepastian dari ahli agama yang mengerti secara mendalam kebingungannya. Ia bingung karena tidak memiliki fondasi keagamaan yang kuat. Ditengah kebingungan ini-lah kemudian dia menuturkan ajaran-ajaran yang ia terima begitu saja, tanpa saringan. ${ }^{16}$ Dalam konteks yang kedua ini, bisa jadi memang yang "mendatangi" Paruru adalah iblis atau setan yang mewujud dan mengaku sebagai Tuhan karena hal itu dimungkinkan dalam dunia sufistik. Bukankah Syekh Abdul Kadir Jaelani, sufi yang paling berpengaruh di Asia Selatan Tenggara -dalam kisah sufistik- pernah juga didatangi suara dalam perjalanan spritualnya yang mengatakan: Hai, Abdul Kadir, telah gugur semua kewajiban bagimu karena Aku ini Tuhan! Abdul Kadir Jaelani lalu berkata: kamu pasti setan! Suara itu berkata: "Dari mana engkau tahu aku setan". Abdul Kadir Jaelani menjawab: Tidak mungkin Tuhan menggugurkan semua kewajibanku sebagai manusia" (wawancara dengan KH. Baharuddin, tanggal 29 Januari 2010). ${ }^{17}$

\section{PENUTUP}

Problem paham keagamaan Paruru adalah persoalan epistemologi yang bercampur baur dengan tarikat yang bersumber dari konsepsi Islam dan religiusitas lokal. Paruru acapkali menggabungkan konsepsi Islam dan konsepsi religiusitas lokal. Salah satu contohnya adalah seorang Tuhan (dari beberapa Tuhan yang dipahami Paruru) yang bernama laailahaillallah berwarna hitam adalah sosok yang lahir dari Kajang (suku di Sulawesi Selatan yang identik dengan warna hitam). Dengan problem seperti itu, pendekatan kepada Paruru tidak bisa dilakukan dengan cara stigmatif. Stigma penyesatan dan pelarangan untuk menyebarkan (sebagai hasil dari pertemuan di Kantor Departemen Agama tanggal 06 Januari 2010), di satu sisi memang cukup baik untuk "mematikan" potensi penyebaran ajaran Paruru "bagi masyarakat,

\footnotetext{
is Syekh Abu Hasan AH bin Idris Al-Ya'qubi ra, seorang sufi dan ulama besar di Baghdaqh mengatakan, "Disingkapkan kepadaku seluruh semesta dari awal sampai akhir dan aku diperkenankan untuk memberi silisilah. Barangsiapa belum diperkenankan maka ia belum-lah seorang syaikh. Ditampakkan kepada-ku para penghuni surga, neraka, alam barzakh, langit dan bumi. Raja-ku telah meletakkan aku di hadapan-Nya dan dengan ke-Maha Murahan-Nya memakaikan jubah yang telah dipilih-Nya dalam azal untukku. Sebuah jubah yang hanya dipakaikan Allah kepada seseorng karena karamahnya. Lihat Lihat Syaikh Muhammad bin Yahya At-Tadafi. 2005. Syaikh Abdul Qadir Al-Jailani, Mahkola Para Aulia Kemuliaan Hamba Yang Ditampakkan-Nya. Jakarta: Prenada Media., h. 330.

${ }^{16}$ Sebagai perbandingan, penulis mempunyai seorang teman akrab yang memiliki "pergulatan" spiritual yang mirip dengan Paruru. Logikanya terhadap agama kadang-kadang terdengar aneh dan di luar kebiasaan. Pertemuan dengan malaikat, iblis, dan ruh orang mati adalah peristiwa biasa. Ia merasa pernah "diperjalankan" ke Mekkah. Dan menurutnya, ia selalu diajar oleh Syekh Abdul Kadir Jaelani, yang disebutnya "Guru Besar". Tetapi menariknya, ia sangat baik dalam menjalankan syariat Islam, terutama shalat dan puasa. Ini karena ia memiliki fondasi fiqhi dan pemahaman agama yang cukup kuat.

${ }^{17}$ Di dunia sufistik, Syekh Abdul Kadir Jaelani dikenal sebagai sufi yang banyak melakukan perang fisik dengan setan. Misalnya salah satu riwayat dari Syekh Utsman Shairafi bahwa Syaikh Abdul Kadir Jaelani bercerita: "Siang malam aku tinggal di Padang Pasir, bukan di Baghdag. Sepanjang masa itu, para setan mendatangiku berbaris dengan rupa yang menaktukan, menyandang senjata dan melontari aku dengan api.Namun, saat itu aku mendapatkan keteguhan hati yang tak dapat aku ceritakan dan aku mendengar suara hatiku yang berkata, 'Bangkit Abdul Kadir! Telah Kami teguhkan engkau dan ketika aku bangkit mereka pun kocar-kacir, kembali ke tempat semula. Setelah itu ada satu setan mendatangiku dan mengancamku dengan berbagai ancaman. Aku bangun dan menamparnya hingga dia lari pontang-panitng. Kemudian aku baca laa hauwla wa laa quwwata ilia billah al-ali al-adzim dan terbakarlah dia". Ibid, h. 25.
} 
tetapi pendekatan itu tidak mampu menyelesaikan problem mendasar dari Paruru, yaitu ilusi tentang Tuhan dan segala ilmu yang diperolehnya secara gaib. Proses penyelesaian kasus Paruru hams dilakukan dengan menggunakan"pemulihan" epistemologi melalui dialog terus menerus.

Paruru perlu didekatkan kepada ulama atau kyai karismatik yang mengerti dunia tarikat dan dunia sufistik. Paruru perlu mendapatkan "sparing partner" pemahaman keagamaan agar tidak menganggap keseluruhan pengetahuannya yang "paling" benar. Paruru menurut penulis sedang mengalami kebingungan spritualitas, mendapatkan pengetahuan yang berserakan sehingga perlu mendapatkan penataan spiritual (terutama penataan syariat) dari para pemuka agama.

Selain dialog, peneliti mengajukan pendekatan lain yaitu pendekatan rukyah. Paruru sangat percaya diri bahwa yang dilihatnya adalah benar-benar Tuhan dan mengajak (atau menantang) siapa-pun orang yang ingin melihat Tuhan. Ruang ini sesungguhnya dapat dimanfaatkan untuk memberikan pembuktian terbalik kepada Paruru. Jika benar yang mendatangi Paruru adalah syetan atau sejenis jin, maka dengan rukyah segalanya menjadi jelas, dan Paruru mendapatkan pemahaman baru bahwa ternyata yang datang bukan Tuhan, tetapi makhluk yang mengaku Tuhan.

\section{DAFTAR PUSTAKA}

Bucaille, M. 1978, Bibel, Qor 'an dan Sains Modern, Alih bahasa; HM. Rasjidi, Bulan Bintang Jakarta.

Fromm, E., 1999, Revolusi Harapan, Pustaka Pelajar, Yogyakarta.

Hasbullah-Bakry, 1961, Nabi Isa dalam Al- Qur'an dan Muhammad dalam Bijbel, Penerbit AB Siti Syamsiah, Solo.

Klausner, J., 1979, "The Source and Beginning og the Messianic Idea", dalam Leo Landman (ed), Messianism in the Talmudic Era, KTAV Publishing House Inc., New York.

Munir, Misnal. t.t Messianisme dalam Pespektif Sejarah, diakses dari Y/wvi.jurnal.filsafat.ugm.ac.id tanggal 02 Maret 2009.

Sachedina, A A., 1981, Islamic Messianisme: The Idea of the Mahdi in Twelver Shi 'ism, State university of New York Press, New York.

Sobrino, J. 1993, "Messiah and Messianism: Reflectians from El Salvador" dalam: Wim Beuken, et.al (Eds), Messianism Throught History, SCM Press, London.

Toffler, A., 1989, Kejutan Masa Depan, Alih bahsa: Sri Koesdiyantinah, PT. Pantja Simpati, Jakarta.

Turner, Brian. S. 1991. Agama dalam PerspektifSosiologi. Kreasi
Wacana, Jogyakarta.

Zayd, Nashr Hamid Abu. 2002. Tekstualitas Qur 'an. LK1S, Jogyakarta.

www. fuui.wordpress.com. Messianisme dalam Persfektif Islam (diakses pada tanggal 02 Maret 2009). 